\title{
SITUS KAMPUNG TUA KAO: \\ Identitas Asal Usul dan Jejak Peradaban Islam \\ di Wilayah Pedalaman Halmahera Utara
}

\section{OLD SETTLEMENT SITE IN KAO: The Origin Identity and Traces of Islamic Civilization in The Hinterland of North Halmahera}

\author{
Wuri Handoko dan Muhammad Al Mujabuddawat \\ Balai Arkeologi Maluku \\ Jl. Namalatu-Latuhalat, Ambon 97118 \\ e-mail: wuri_balarambon@yahoo.com,mujab@kemdikbud.go.id
}

Naskah diterima tanggal: 12-9-2017, disetujui tanggal: 28-9-2017

\begin{abstract}
Tanah Kao as part of Ternate's Islamic rule is not mentioned in many historical literatures which is dominated by sources about Tobelo in relation to the history of Hibualamo and the Moro Kingdom. However, based on the people's folklore, it is said that the identity of the origin of North Halmahera community derives from Telaga Lina in Tanah Kao. Based on the folklore, this research was conducted in the Kampung Tua Kao (Old Settlement Site in Kao). This research reveals the identity of the people who inhabit the Kampung Tua Kao and the traces of Islamic civilization on Kampung Tua Kao by using literature study, field survey, and archaeological excavation. Based on the results of literature studies and previous research there are theories that explain the identity of the origin of the Kao people but entirely derived from Telaga Lina in the Tanah Kao. Based on archaeological survey and excavation in the Kampung Tua Kao, it was found a number of archaeological remains in the form of artifacts and features. The remaining artifacts were found in various fragments of earthenware and foreign ceramics, while the remaining features encountered including a number of ancient tombs, grave tombs, lutur, and mosque poles. Based on these data, this study proves the existence of the Muslim community who has lived and inhabited the Kampung Tua Kao in the past and there are various cultural interactions within the community.
\end{abstract}

Keywords: Archaeology, Islamic civilization, old settlement, Kao, North Halmahera

\begin{abstract}
Abstrak: Hubungan Tanah Kao dengan kekuasaan Islam Ternate di Halmahera Utara tidak banyak disebutkan dalam berbagai literatur. Sebagian besar literatur menyebut tentang Tobelo dalam kaitannya dengan sejarah Hibualamo dan Kerajaan Moro. Namun, berdasarkan tradisi tutur masyarakat menyebutkan bahwa identitas asal-usul komunitas orang Halmahera Utara berasal dari Telaga Lina di Tanah Kao. Atas dasar tradisi tutur itulah yang menjadi dasar penelitian di Situs Kampung Tua Kao. Penelitian ini mengungkap penelusuran identitas komunitas yang mendiami situs Kampung Tua Kao pada masa lalu dan jejakjejak peradaban Islam di situs Kampung Tua Kao dengan menggunakan metode penelusuran kepustakaan, survei lapangan, dan ekskavasi arkeologi. Hasil penelitian ini mengungkapkan berdasarkan hasil penelusuran pustaka dan penelitian terdahulu terdapat sejumlah teori yang menjelaskan identitas asal-usul komunitas Kao. Namun, apabila dirunut ke belakang semuanya berasal dari Telaga Lina di Tanah Kao. Berdasarkan survei dan ekskavasi arkeologi di situs Kampung Tua Kao ditemukan sejumlah tinggalan arkeologis berupa artefak dan fitur. Tinggalan artefak yang ditemukan antara lain beragam fragmen gerabah dan keramik asing, sedangkan tinggalan fitur yang dijumpai antara lain sejumlah makam kuno, nisan
\end{abstract}


makam, lutur, dan umpak-umpak masjid. Berdasarkan data-data tersebut, penelitian ini membuktikan keberadaan komunitas muslim pernah hidup dan mendiami situs Kampung Tua Kao di masa lalu dan terjadi berbagai interaksi budaya di dalam komunitas tersebut.

Kata kunci: Arkeologi, peradaban Islam, perkampungan tua, Kao, Halmahera Utara

\section{PENDAHULUAN}

Wilayah Kecamatan Kao yang disebut dengan Tanah Kao merupakan bagian dari wilayah Kabupaten Halmahera Utara, yang beribukota di Tobelo dan dikenal dengan sebutan Bumi Hibualamo (Naping, 2013). Tanah Kao dalam berbagai literatur sejarah Islam di bumi Halmahera Utara selama ini tampaknya dibahas dalam porsi yang terbatas dan tidak utuh sebagai bagian dari penelusuran sejarah yang lengkap dalam historiografi lokal di wilayah Halmahera Utara. Selama ini penulisan tentang sejarah dan budaya di Tanah Kao dan hubungannya dengan kekuasaan Islam Ternate, ditulis menjadi bagian dari Kerajaan Moro dan Tobelo yang lebih populer. Menyangkut wilayah Tobelo, banyak sumber menuliskan bahwa suku bangsa Tobelo merupakan suku bangsa yang banyak dijumpai di sejumlah wilayah karena adanya proses migrasi yang luas. Orang Tobelo dijumpai di sekitar Teluk Kao, bagian utara Pulau Morotai, di daerah Weda, Maba, dan Gane, Kepulauan Bacan, bahkan di Pulau Obi (Naping, 2013). Sedangkan suku yang beragama Islam yaitu Pagu, Tololiku, dan Modole tinggal ke arah pedalaman Kao. Namun, jika berdasarkan sejarah terbentuknya komunitas di Halmahera Utara, maka posisi Tanah Kao sangat penting karena dari wilayah inilah sesungguhnya cikal bakal tumbuh dan menyebarnya komunitas di Halmahera Utara. Asal komunitas penduduk Halmahera Utara berasal dari Telaga Lina, yang terletak di daratan Tanah Kao. Kurangnya informasi yang utuh tentang wilayah Tanah Kao dapat dipahami mengingat minimnya sumber sejarah yang menuliskan tentang Tanah Kao. Beberapa sumber sejarah menuliskan atau memberi informasi tentang Kao sekadarnya. Catatan tentang sejarah Halmahera lebih banyak didominasi oleh sumber-sumber sejarah yang menyebut tentang Tobelo dalam kaitannya dengan sejarah Hibualamo dan Kerajaan Moro.

Pada beberapa literatur, peneliti lebih banyak mengangkat Tobelo yang sangat identik dengan kawasan jazirah Halmahera Utara dan menghubungkannya dengan Telaga Lina yang secara geografis berada di wilayah Kao. Terlepas dari penulisan sejarah yang ada, dalam perspektif arkeologi justru terlihat bukti yang valid tentang peran dan kedudukan Kao dalam konteks sejarah peradaban Islam dan jaringan perdagangan di wilayah Halmahera Utara dengan wilayah lainnya tanpa menafikan peran wilayah lainnya seperti Tobelo dan Galela dalam konteks eksistensi Kerajaan Moro.

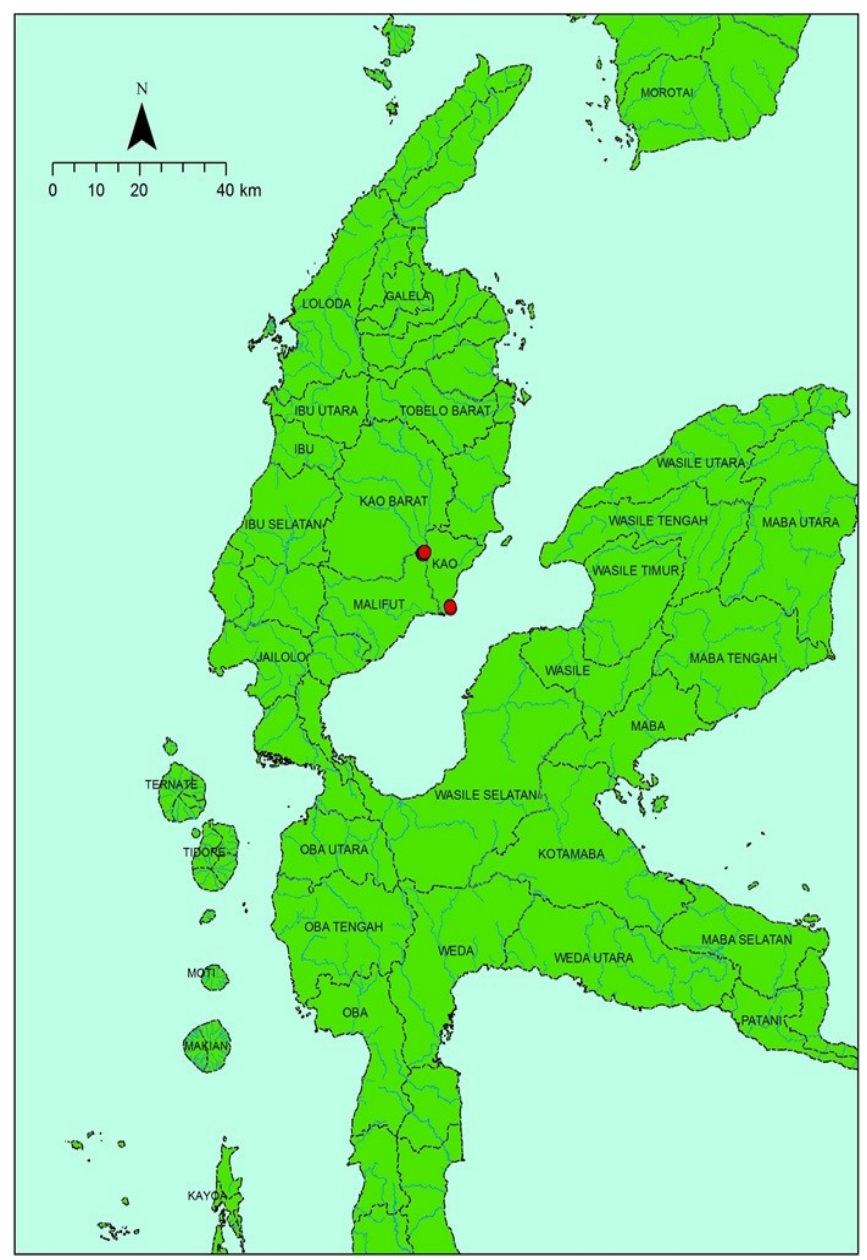

Gambar 1 Lokasi Tanah Kao 
Bernard HM Viekke dalam Nusantara a History of Indonesia, yang dikutip oleh Diense \& Thaib (2008), disebutkan bahwa sejak abad ke-10 telah ada struktur negara yang modern di kawasan Moloku Kie Raha. Semua ini terjadi karena relasi multietnik akibat jalinan perdagangan rempah-rempah yang terbentuk jauh sebelum era Kristen. Rute perdagangan rempahrempah itu merupakan bentuk dominasi dari Kepulauan Ternate yang dikuasai oleh Kesultanan Ternate (Nomay, 2014). Dalam beberapa literatur, selain wilayah Kepulauan Maluku bagian Selatan, Kesultanan Ternate juga melakukan ekspansi ke wilayah-wilayah di bagian Maluku Utara, terutama daratan Pulau Halmahera. Wilayah Kesultanan Ternate meliputi Pulau Ternate, Moti-Makian, Pulau-pulau Kayoa, Jailolo, Ibu, Loloda, Tobelo, Galela, Morotai, Gane Timur, Gane Barat, Kepulauan Sula, Tobuku, dan Banggai (Asyhari, 2008). Penelitian arkeologi di wilayah pesisir utara Pulau Halmahera tampaknya masih minim, terutama yang berkaitan dengan arkeologi sejarah. Sejauh ini, penelitian arkeologi di wilayah ini berfokus pada penelitian arkeologi prasejarah yang beberapa diantaranya dilakukan oleh peneliti asing. Selain itu, penelitian yang fokus pada penelitian sejarah Islamisasi di Halmahera Utara yang berkaitan dengan sejarah Kesultanan di Maluku Utara masih sangat terbatas.

Penelitian arkeologi yang bertumpu pada budaya kebendaan membantu kita menemukan informasi dari berbagai peninggalan budaya masa lampau, baik yang berbentuk artefaktual maupun fitur-fitur bangunan monumental yang masih bisa disaksikan saat ini, serta berbagai makna simbolik dibalik benda budaya itu. Konteks penelitian ini tergolong ke dalam kategori pendekatan arkeologi sejarah (historical archaeology). Termasuk di dalamnya arkeologi Islam (Islamic archaeology), yaitu arkeologi yang mempelajari masyarakat Islam masa lampau melalui artefak, fitur, dan ekofak yang dihasilkan dari masyarakat masa lampau pada masa sejarah, yakni masa ketika sudah mengenal tulisan (Tjandrasasmita, 2009). Azra
(2009) mengatakan arkeologi merupakan salah satu ilmu yang sangat dekat dengan sejarah, karena tujuannya sama, yakni mengungkap kehidupan manusia pada masa lalu. Perbedaan keduanya lebih banyak pada penggunaan sumber, yaitu sejarah lebih banyak bersandar pada sumber tertulis, sedangkan arkeologi pada sumber berupa benda atau artefak yang antara lain diperoleh melalui ekskavasi.

Kajian sejarah Islam sebelum abad ke-15 sangat memerlukan dukungan bukti-bukti arkeologis. Sejarah masuk dan berkembangnya Islam di Indonesia sekitar abad ke-13 hingga abad ke-15 masih menyisakan banyak pertanyaan yang memerlukan jawaban atas dasar berbagai bukti, khususnya arkeologi. Hasil penelitian arkeologi menjadi domain yang penting untuk mengungkap sejarah budaya, terutama soal bagaimana perkembangan Islam dalam periode tertentu yang kurang terangkat dalam studi sejarah. Misalnya, tentang dinamika Islam dan budaya lokal melalui analisis serangkaian data artefaktual maupun situs yang dapat membantu melengkapi informasi sejarah (Handoko, 2014; Mujabuddawat, 2016). Oleh karena itu, penggunaan data dan bukti arkeologi untuk pengungkapan sejarah Islam Indonesia menjadi sangat penting.

Dalam proses pencarian dan pengumpulan data diperlukan pengetahuan atau sekurangkurangnya mengerti apa yang disebut arkeologi dan atau sejarah (Tjandrasasmita, 1998; Tjandrasasmita, 2009). Tjandrasasmita selanjutnya menjelaskan baik arkeologi maupun sejarah terdapat sedikit perbedaan definisi. Arkeologi dalam studinya lebih menitikberatkan kepada benda-benda atau artefak yang tidak perlu ada tulisan, sedangkan sejarah dalam studinya lebih mengutamakan data-data tertulis, seperti arsip dan dokumen. Keduanya bertujuan sama, yakni untuk merekonstruksi kehidupan masyarakat masa lampau. Sumber peninggalan arkeologis dapat berupa artefak maupun fitur yang keduanya dapat mengandung tulisan. Benda atau bangunan dari masa sejarah yang tidak mengandung tulisan pun masuk 
dalam kategori arkeologi sejarah. Dalam mencari dan mengkajinya dapat menggunakan data tekstual seperti arsip, dokumen-dokumen, naskah-naskah kuno tentang hikayat, babad, bahkan dongeng ataupun legenda karena mengandung kebenaran atau kenyataan (de Graaf, 1956; Tjandrasasmita, 2009). Menurut Tjandrasasmita (2009), proses Islamisasi suatu wilayah diperlukan refleksi mengingat banyaknya pertanyaan tentang kelompok asal-usul yang membawa dan memperkenalkan Islam, termasuk jaringan yang digunakan. Jangka waktu antara kedatangan dan penyebaran Islam, khususnya kemunculan kerajaan-kerajaan Islam merupakan proses panjang bertahun-tahun. Proses Islamisasi terjadi lewat jaringan yang beragam, yang secara alamiah menguntungkan masingmasing pihak, yaitu baik bagi orang Muslim yang datang dan menyebarkan Islam ke berbagai tempat dan bagi orang-orang yang menerima atau beralih ke Islam di wilayah tersebut. Penyebaran Islam beserta prosesnya dapat dilakukan melalui jalur yang beragam seperti perdagangan, perkawinan, tasawuf, pendidikan, kesenian, dan politik (Ghofur, 2011).

Islam dianggap telah masuk ke Maluku Utara pada sekitar abad ke-14, seperti yang terkandung dalam tradisi lisan yang menyebutkan bahwa Raja Ternate XII akrab dengan para pedagang Arab (Ambary, 1996; Mansyur, 2007). Kedatangan Islam ke Indonesia bagian Timur yaitu ke Maluku, tidak dapat dipisahkan dari jalan perdagangan yang terbentang antara pusat lalu lintas pelayaran Internasional di Malaka, Jawa, dan Maluku. Diceritakan bahwa pada abad ke-14 Raja Ternate XII, Molomateya, (1350-1357) bersahabat baik dengan orang Arab yang memberikan petunjuk bagaimana pembuatan kapal-kapal, bukan dalam hubungan agama. Menurut tradisi setempat, sejak abad ke-14 Islam sudah datang di daerah Maluku. Pengislaman di daerah Maluku dibawa oleh Maulana Husayn. Hal ini terjadi pada masa pemerintahan Sultan Marhum di Ternate (Yatim, 2006). Maulana Husayn pada mulanya hanya menunjukan kemahiran dalam menulis huruf Arab yang ada dalam Alquran, sehingga menarik hati Sultan Marhum dan orang-orang Maluku. Mereka tidak hanya diajarkan tulisan Arab yang indah saja, tetapi juga diajarkan tentang agama Islam (Poesponegoro \& Notosusanto, 2008). Raja pertama yang benar-benar muslim adalah Zainal Abidin (1486-1500) yang mendapat ajaran agama dari Madrasah Giri. Zainal Abidin ketika di Jawa terkenal sebagai Raja Bulawa, artinya Raja Cengkeh karena membawa cengkeh dari Maluku untuk persembahan. Tokoh yang mengantar raja Zainal Abidin ke Giri yang pertama adalah Jamilu dari Hitu. Ketika ia kembali dari Jawa, Zainal Abidin membawa mubalig yang bernama Tuhubabahul sehingga hubungan Ternate, Hitu dengan Giri di Jawa Timur menjadi sangat erat.

Penelitian ini bertujuan untuk menelusuri jejak Islamisasi di wilayah pedalaman Halmahera Utara, dengan menempatkan wilayah Kao sebagai posisi sentral dalam jaringan Islamisasi tersebut. Penelitian arkeologi tahun 2014 di wilayah pesisir timur Halmahera Utara dan dilanjutkan pada tahun 2016, menemukan indikasi permukiman di daerah aliran sungai (DAS) Akejodo, Kecamatan Kao. Dari hasil wawancara dengan penduduk Desa Kao, diperoleh informasi bahwa permukiman tua tersebut adalah bekas kampung masyarakat Kao sebelum tinggal di pesisir pantai sekarang ini. Pada wilayah ini ditemukan situs permukiman komunitas Islam yang sekaligus di dalamnya juga ditemukan kompleks sebaran makam kuno Islam. Permukiman tua tersebut selanjutnya disebut Situs Kampung Tua Kao.

Penelitian ini menitikberatkan peran wilayah Tanah Kao dalam kedudukannya sebagai wilayah strategis bagian dari kekuasaan Islam Kesultanan Ternate, sekaligus sebagai salah satu titik sentral penyebaran Islam di Bumi Halmahera. Penjelasan menyangkut perkembangan Islam selama ini banyak membahas tentang Islamisasi dan perkembangannya di wilayah-wilayah yang dianggap sebagai pusat peradaban. Sementara itu, peran daerah lain sebagai wilayah satelit dari kekuasaan Islam jarang diangkat dalam 
diskusi akademis. Argumentasi yang mengemuka menyebutkan bahwa pusat kekuasaan Islam membutuhkan daerah-daerah penyangga untuk memperkuat eksistensi kekuasaan dan sekaligus eksistensi Islam itu sendiri. Berdasarkan argumentasi, ada dua rumusan masalah dalam tulisan ini. Pertama, bagaimana sejarah asalusul komunitas yang mendiami Situs Kampung Tua Kao pada masa lalu? yaitu di masa pra dan awal kedatangan Islam. Kedua, bagaimana jejak peradaban Islam di Situs Kampung Tua Kao berdasarkan hasil penelitian arkeologi?

\section{METODE}

Tulisan ini menggunakan metode penelusuran pustaka dan penelitian lapangan. Dalam menganalisis sejarah dan identitas asal-usul komunitas yang mendiami kampung tua Kao, penelitian ini merujuk pada penelusuran pustaka dan penelitian terdahulu terkait sejarah Islam di Halmahera Utara. Dalam memperoleh data jejak peradaban di Situs Permukiman Tua Kao, selain melakukan survei lapangan, dilakukan penelitian dengan metode ekskavasi pada Maret 2016. Pada konteks penelitian metode ekskavasi ini dilakukan tespit, yakni melakukan penggalian pada areal situs yang dianggap potensial untuk mengungkap data arkeologi di bawah tanah yang dapat mengungkap sejarah budaya masa lampau Situs Kampung Tua Kao. Data ekskavasi digunakan untuk mengetahui kepadatan temuan di bawah tanah dan mengetahui intensitas dan kronologi hunian. Berdasarkan layer-layer tanah yang digali maka dapat diidentifikasi lapisan budaya atau kronologi hunian dan perkembangan pada masyarakat pendukungnya di masa lampau. Ekskavasi atau tespit dilakukan di areaarea yang diidentifikasi sebagai lokasi hunian.

\section{HASIL DAN PEMBAHASAN \\ Sejarah dan Identitas Asal Usul Komunitas Orang Kao}

Wilayah Tanah Kao sebagai wilayah adat dari pulau besar Halmahera, memiliki posisi penting khususnya di wilayah Halmahera Utara. Dalam beberapa catatan hasil penelitian, wilayah Kao tidak dapat dilepaskan dari serangkaian penelitian tentang asal-usul manusia yang menghuni Pulau Halmahera. Pulau Halmahera merupakan bagian dari wilayah Maluku yang merupakan daerah persebaran budaya Austronesia yang dibawa oleh suku bangsa atau ras Austro Melanesia (Handoko, 2007b). Dari masa yang sangat lampau, telah ditemukan indikasi hunian awal manusia, bahkan temuan purbakala di daerah Doro dan Tanjung Luari (Kao dan Tobelo) dihubungkan dengan teori tentang tanah asal penduduk berbahasa Austronesia, sebagaimana hipotesis yang diajukan oleh Richard Shutler (Soegondho, 1995; Amal, 2010). Meski demikian, dalam berbagai catatan penelitian, bahasa yang berkembang di wilayah Halmahera Utara saat ini merupakan pertemuan Bahasa Austronesia dan Non-Austronesia. Disebutkan bahwa Halmahera bagian utara pada sekitar tahun 3.300 SM s.d. 2.300 SM telah dihuni oleh bangsa Non-Austronesia yang membangun permukiman dan mengembangkan budaya neolitik. Bangsa Austronesia datang dengan membawa unsur-unsur budaya baru. Permukiman bangsa Non-Austronesia dan Austronesia dibangun berdekatan. Terjadi interaksi budaya antara dua jenis bangsa tersebut. Pada fase berikutnya, antara tahun 2.300 SM s.d. 1.000 SM bangsa Austronesia semakin menguat sehingga mendesak eksistensi bangsa NonAustronesia. Bangsa Non-Austronesia terdesak ke pedalaman dan sebagian ke arah timur kepulauan Maluku bagian utara sehingga terbangunlah jaringan pelayaran dan perdagangan di wilayah kepulauan Maluku bagian utara (Wimbish, 1991).

Dengan demikian, Halmahera bagian utara merupakan perlintasan yang sangat penting dalam proses kolonisasi bangsa Austronesia dan non-Austronesia. Fase-fase perkembangan migrasi-koloni bangsa-bangsa Austronesia dan Non-Austronesia dapat direkonstruksi dalam lima fase. Fase 1, migrasi koloni bangsa nonAustronesia. Pantai timur dari Halmahera bagian utara merupakan bagian jalur migrasi bangsa Non-Austronesia. Pada periode tertentu 
diperkirakan sebagian dari bangsa nonAustronesia membangun koloni di kawasan pantai timur tersebut. Fase 2, migrasi Bangsa Austronesia. Persebaran bangsa Austronesia di wilayah kepulauan Maluku bagian utara di antaranya melalui jalur pantai timur Halmahera, terjadi kontak antara bangsa non-Austronesia dengan bangsa Austronesia di kawasan tersebut. Fase 3, terjadi interaksi budaya bangsa Austronesia dan bangsa non-Austronesia. Pada periode tertentu bangsa Austronesia membangun permukiman berdampingan dengan permukiman bangsa non-Austronesia di kawasan pantai timur Halmahera bagian utara. Fase 4, terjadi eksodus ke pedalaman. Bencana besar yang berdampak global diduga telah terjadi, sehingga memaksa komunitas-komunitas yang berada di pesisir melakukan perpindahan ke pedalaman, baik dengan melewati jalur darat maupun sungai. Fase 5, membangun koloni baru. Pada saat eksodus tersebut interaksi antara dua bangsa semakin intensif dan bersama-sama membentuk komunitas baru. Komunitas baru tersebut kemudian berhenti di Telaga Lina dan membangun koloni baru di tempat tersebut (Wimbish, 1991).

Leluhur penduduk yang sekarang disebut Kabupaten Halmahera Utara adalah campuran antara orang dengan latar kebudayaan dan bahasa Austronesia dan non-Austronesia. Sekalipun terbagi atau dapat dibedakan dalam sejumlah etnik, semuanya mempercayai bahwa komunitas Telaga Lina merupakan leluhur atau cikal bakal mereka. Telaga Lina ini berada di pedalaman, di lereng Gunung Rau dan terletak tepat pada titik tengah Halmahera bagian Utara. Bila berpatokan pada batas-batas daerah, maka Telaga Lina terletak di sebelah barat daya Tobelo; di sebelah selatan Galela; di sebelah tenggara Loloda; dan di sebelah timur daerah Ibu; sedangkan di sebelah utara ada daerah Jailolo dan di sebelah barat laut terletak daerah Kao (Puasa, 2013). Bahasa-bahasa antara mereka berbeda tetapi dapat saling mengerti dan memahami bahasa tersebut. Perbedaan bahasa bisa dikatakan sebagai perbedaan dialek saja. Dari sembilan hoana atau soa yang bersumber dari cikal bakal mereka di Telaga Lina, empat di antaranya eksodus ke Tobelo dan lima lainnya ke Kao. Mereka yang di Tobelo adalah: Gura, Mumulati, Huboto, dan Lina. Sedangkan yang menetap di Kao adalah Togehoro, Tuguis, Kanaba, Modole, dan Pagu.

Putuhena (1995) dan Amal, (2010), yang telah mengutip catatan Sarasin Bersaudara bahwa orang-orang Kao, Tobelo, Ibu, Sahu, Galela dan lain-lainnya kemungkinan merupakan rangkaian dari gelombang datangnya orang Melayu ke Maluku Utara. Sarasin mengungkapkan, setelah orang Negroid, datang pula orang Melayu ke Maluku dalam dua gelombang. Gelombang pertama disebut proto-Melayu dan gelombang kedua doutro-Melayu. Setelah kedatangan gelombang kedua, proto-Melayu terdesak. Untuk mempertahankan eksistensinya, mereka menyingkir ke daerah pedalaman serta membentuk komunitas tersendiri. Orang-orang Alifuru di pedalaman Halmahera dan suku-suku terasing lainnya diperkirakan berasal dari kelompok yang tersingkir ini. Mereka lazimnya mendiami tepian danau atau hulu sungai serta terdiri dari beberapa suku yaitu suku Tobaru di Galela, Wayoli di Sahu, Boenge di Ibu, Pagu di Kao, Kusuri di Tobelo, dan suku-suku lainnya yang terdapat di Halmahera Timur serta kepulauan Sula. Walaupun bagian terbesar dari suku-suku ini telah dimukimkan kembali, sisasisanya masih dapat ditemukan terutama di Halmahera Utara dan Halmahera Timur (Putuhena, 1995; Amal, 2010).

Pada beberapa sumber tentang sejarah dan peradaban di Halmahera Utara, selalu dihubungkan dengan Tobelo dan sedikit menyebut Kao. Padahal, tanah asal tentang komunitaskomunitas yang berkembang di Halmahera Utara sesungguhnya berawal dari Telaga Lina di pedalaman Tanah Kao. Dalam catatan sejarah, rekonstruksi sejarah awal masyarakat yang kini mendiami Kabupaten Halmahera Utara mengacu pada tradisi lisan yang berkembang di masyarakat. Pada umumnya, periodisasi kisah dalam tradisi lisan tidak jelas karena tidak adanya 
penanggalan dalam kisahnya. Awal mula masyarakat Halmahera Utara dituturkan berasal dari Tanah Semenanjung, tepatnya Johor. Mereka berjumlah tiga orang. Dalam pelayaran meninggalkan negerinya itu, dua orang singgah di Pulau Jawa yakni Sarjamin dan Gajadea, sementara satu orang lainnya bernama Waljamin yang meneruskan pelayarannya ke kawasan Timur. Dengan menggunakan perahu juanga, Waljamin kemudian tiba di sebuah pulau yang terletak di bagian barat Pulau Halmahera, Bacan, setelah sebelumya diterpa angin topan di tengah samudera. Tempat berlabuhnya perahu tersebut kemudian dinamakan dengan Juanga Ruba-ruba (Naping, 2013). Dari pulau itu, dia kembali berlayar menuju daratan besar sampai akhirnya tiba di Kao, bagian selatan selatan Halmahera Utara, tepatnya di daerah Bori yang sekarang termasuk dalam wilayah Kao Utara. Perjalanan diteruskan ke pedalaman, sampai tiba di Danau Lina (Telaga Lina). Di Danau Lina inilah terbentuk dan berkembang masyarakat yang tinggal bersama pada sebuah rumah besar yang kelak dinamakan Hibualamo. Pola tinggal macam ini sangat strategis dalam mempertahankan diri di tengah ancaman lingkungan, terutama binatang buas yang sewaktu-waktu dapat mengancam keselamatan hidup mereka.

Menurut legenda-legenda yang dicatat berbagai pejabat di abad ke-19, orang Tobelo berasal dari sekitar Danau Lina di kaki Gunung Tolo. Struktur sosialnya yang masih sangat sederhana berupa kolektivitas hoana (keluarga) yang membentuk empat komunitas yang masingmasing berintikan satu suku, yaitu suku-suku Lina, Hubato, Momulate, dan Gura. Oleh sebab itu, orang Ternate menamakan mereka "manusia soa raha" (orang dari empat rumah atau empat keluarga). Sekitar abad ke-17 mereka mulai meninggalkan daerah asal dan pindah ke pantai dan sejak itulah mereka mulai dikenal sebagai bajak laut. Sekitar masa itu pula kekuasaan Ternate yang sudah tertanam antara lain di Gamkonora, Loloda, dan Jailolo mulai menjangkau ke permukiman-permukiman Tobelo. Orang Tobelo sejak itu mempunyai hubungan politik tertentu dengan penguasa negeri Gamkonora seperti halnya sebagian dari masyarakat Halefuru lainnya di Jazirah Utara (Leirissa, 1990). Sejak sekitar abad ke-18, Ternate mengangkat seorang pemimpin dalam suku Lina yang telah beragama Islam kemudian disahkan sebagai Bobato untuk orang-orang Tobelo. Sekitar masa itu pula suatu kelompok dari orang-orang Tobelo memisahkan diri dan berpindah ke wilayah Kao dimana mereka juga membagi diri menjadi empat suku, yaitu Boeng, Tunai, Seleruru, dan Madang. Ketika itulah rupanya oleh Ternate mereka dianggap sebagai bagian dari kekuasaan distrik Kao (Amal, 2010; Naping, 2013).

Para penguasa negeri menggunakan gelar jabatan Sangaji, sedangkan para kepala kampung menggunakan gelar Kimelaha ataupun Nqofamanyira. Terkait kekuasaan menjadi jelas, bahwa di Halmahera dan di wilayah-wilayah lainnya di Maluku Utara, para sangaji adalah penguasa suatu "distrik" (landschap) yang terdiri atas satu negeri induk dan berbagai permukiman (kampung) lainnya. Dengan demikian sangaji di Halmahera adalah semacam "Raja" yang kedudukannya mempunyai otonom dari Sultan, terutama di Halmahera Timur. Hal itu terutama terlihat dari istilah soasiu yang juga digunakan untuk negeri induk setiap distrik di Halmahera (Leirissa, 1990). Asal-usul komunitas Tobelo yang juga berasal dari wilayah Kao, Leirissa menuliskan bahwa pada abad ke-19 di distrik Weda banyak berdiam diri orang Tobelo yang daerah asalnya adalah Distrik Kao di Halmahera Utara, yang termasuk dalam wilayah kekuasaan Ternate (Leirissa, 1990; Naping, 2013). Penjelasan Leirissa tersebut sebagaimana yang dikutip oleh Naping, yang menegaskan bahwa wilayah distrik Kao merupakan wilayah yang sangat penting dalam kekuasaan Islam Ternate. Bahkan di wilayah distrik Tobelo di bagian tengah Halmahera banyak dihuni oleh orang-orang Tobelo yang asal usulnya berasal dari distrik Kao.

Setelah sekian lama bermukim di kawasan Telaga Lina, sebagian dari mereka memutuskan mencari kehidupan di tempat lain dan sebagian 
tetap bermukim di sana. Mereka yang meninggalkan Telaga Lina, terbagi dalam sepuluh kelompok kecil yaitu: Modole, Pagu, Towoliku, Boe, Lina, Momolati, Huboto, Gura, Morodina dan Morodai (Papilaja, 2011; Naping, 2013). Empat kelompok pertama (Modole, Pagu, Towiliko, dan Boe) menuju daerah dan bermukim di wilayah Kao. Kelompok hoana (perkampungan) Pagu menempati wilayah Kao Selatan sampai Bobane Igo, termasuk wilayah Malifut dan Kao Teluk. Kelompok Boe (Boeng) menempati hamparan Kao Utara meliputi PediwangGamlaha. Kelompok ini dianggap sebagai sekaum dengan Lina, Huboto, Mumulati dan Gura yang sekarang adalah orang Tobelo. Kelompok berikutnya, Tiwilako mendiami kawasan Kao Pusat (Kao Staat). Kelompok ini menurut tradisi lisan penduduk dipandang sebagai Orang Tua dalam kelompok Tobelo. Maka terikrarlah Sumpah Towiliko sebagai komitmen hidup bersama bahwa 'terikat menjadi satu, jangan terpisah, hidup bersama dan makan bersama, dan bila berpisah, maka berpisah pun sama-sama (Papilaja, 2011; Naping, 2013).

Selain yang meninggalkan Telaga Lina, ada juga kelompok Modole yang masih tetap tinggal. Mereka menempati kawasan Telaga Lina, yang sekarang tercakup dalam wilayah Kao Barat. Tobaru, Togehoro, dan Kanaba adalah kelompok-kelompok kecil (disebut Tobaru) selain hoana (perkampungan) Kukumutuk, Tolabit, Torawat, Toboulamo (disebut Togutil) berada dalam ayoman Modole. Kelompok Modole dipandang sebagai kelompok awal yang mendiami kawasan Telaga Lina sehingga sering disebut "Sudah Tua" dibandingkan dengan kelompok Tobaru dan Togutil. Tiga kelompok berikutnya, (Lina, Momoloti, Huboto, dan Gura) menetap di daerah yang sekarang disebut Tobelo. Kelompok Lina menempati Paca-Pitu yakni Tobelo bagian tengah, selatan, timur, dan barat. Sebelum tersebar di empat lokasi itu, mereka menempati satu wilayah yang disebut Paca. Kelompok Morodina (Towara dan Kadina) menempati daerah Galela pesisir dan Loloda. Mereka bermukim di bagian barat dan selatan Galela, serta Loloda dan pulau-pulau sekitarnya. Kelompok terakhir, kelompok Morodai (Toweka atau Kadai) umumnya menempati wilayah Galela Kota (sekarang) serta Morotai dan pulau-pulau sekitarnya (Naping, 2013).

Dari uraian di atas dapat dilihat hubungan antara komunitas orang Kao dengan komunitaskomunitas lain yang sekarang bermukim di wilayah pesisir timur bahkan utara Halmahera Utara. Dalam beberapa bagian, komunitas orang Kao, dapat dirunut ke belakang sebagai komunitas cikal bakal dari komunitas-komunitas lainnya seperti Tobelo, Galela dan juga Loloda. Identitas asal-usul komunitas yang sekarang bermukim di wilayah Halmahera Utara dapat dirunut ke belakang, semuanya berasal di wilayah Telaga Lina, sebuah wilayah yang termasuk dalam wilayah daratan Tanah Kao sekarang. Dengan demikian, komunitas Orang Kao yang sekarang menempati wilayah Boeng, Modole, Pagu, dan Tololiko, merupakan komunitas suku yang peranannya dalam penjelasan soal identitas asal-usul komunitas Halmahera Utara, bahkan berhubungan pula dengan terbentuknya Kerajaan Moro dan Loloda. Oleh karena itu, dari latar historis yang dikemukakan, tampaknya penelusuran bukti-bukti sejarah harus seimbang dan proporsional untuk menghindari berbagai penulisan sejarah yang reduksi. Data-data sejarah baik tutur, sejarah tertulis, dan berbagai fakta arkeologi di lapangan, merupakan data yang komprehensif untuk menjelaskan perjalanan sejarah komunitas Kao tentang asal-usul identitas komunitas suku yang bermukim di wilayah Halmahera Utara.

Dalam sejarah disebut bahwa wilayah Kao di Halmahera Utara adalah salah satu distrik yang sudah tua, dan sangaji Kao sudah dikenal sejak abad ke-16. Pada tahun 1686 di permukiman utama Kao ada sekitar 140 jiwa yang semuanya muslim dan sekitar 60 jiwa halifuru. Pada permukiman di Tololiku ada 35 jiwa, Pagu 40 jiwa, dan Modole 30 jiwa. Menurut Campen, dalam sebuah publikasinya tahun 1883, Distrik Kao menempati wilayah Kao, Boeng, Pagu dan Modole dan setiap wilayah dikepalai oleh sangaji 
yang mengurusi administrasi politik dan komunitas sosial kemasyarakatan (Naping, 2013). Wilayah Kao, terbagi lagi menjadi beberapa permukiman yakni Pesisir Kampung Kao, yang pada sekitar 1880 berada di muara sungai besar Kao. Di sini bermukim orang Ternate, muslim dari Kao, Halefuru, dan beberapa orang Cina. Pada tempat ini pula Sangaji Kao bertempat tinggal. Permukiman lain adalah Soa Tofkange yang merupakan permukiman utama (Naping, 2013; Amal, 2010). Permukiman utama orang Kao diperkirakan berhubungan dengan situs arkeologi berupa permukiman kuno Kao, yang biasa disebut juga Kampung Tua Kao (Tim Penelitian, 2014). Berdasarkan informasi masyarakat setempat, masyarakat Kao yang sekarang bermukim di pesisir, pada masa lampau bermukim di Situs Kampung Tua Kao yang terletak di pinggir sungai Air Kalak, yang muaranya terletak di sebelah utara. Pada tahun 1904, penduduk Kao lama pindah ke permukiman yang saat ini ditempati di pesisir pantai. Desa Kao di pesisir pantai berbatasan sebelah utara dengan Kao Utara, sebelah selatan dengan Kecamatan Malifut, sebelah timur dengan Teluk Kao, dan sebelah barat dengan Kecamatan Kao Barat. Lokasi situs kampung lama, termasuk dalam wilayah Kecamatan Kao Barat, tepatnya 2 km sebelah barat Desa Popon (Tim Penelitian, 2014; Handoko dkk., 2016).

\section{Situs Kampung Tua Kao: Jejak Pusat Peradaban Islam di Bumi Hibualamo Jaringan Islamisasi: Ternate dan Perluasan Islam di Wilayah Pedalaman}

Wilayah Kao terletak di pesisir timur Halmahera Utara adalah satu dari sekian wilayah di bagian utara Pulau Halmahera yang kaya sumber daya, baik alam maupun sumber daya budaya. Ragam tinggalan budaya bersinggungan erat dengan kekayaan sumber daya alam, berupa tambang emas. Eksploitasi tambang sudah lama berlangsung, kira-kira sejak pertengahan tahun 90an. Laju eksploitasi sumber daya alam ternyata berbanding terbalik dengan upaya penggalian sumber daya budaya yang lama tak tersentuh. Sumber daya budaya sebagai domain penting dalam pelacakan bukti-bukti sejarah dan perkembangan peradaban tampaknya masih terpendam jauh dalam memori kolektif publik. Tanah Kao, wilayah yang kaya sumber daya alam, namun dilupakan jejak peradabannya. Kao adalah wilayah Halmahera yang dalam literatur tidak banyak diungkap, padahal jejak peradaban masa prasejarah ditemukan di sana. Dalam masa sejarah, Tanah Kao tidak dapat dipisahkan dari identitas asal-usul komunitas suku di Halmahera. Namun, namanya kalah kesohor dibanding Tobelo dan Galela yang dikenal dalam sejarah Kerajaan Moro. Telaga Lina adalah sebuah lokasi di pedalaman Tanah Kao, disebut-sebut sebagai tanah asal-usul suku yang bermukim di Halmahera Utara, yang diantaranya suku Tobelo, Galela, Kao, dan suku-suku lainnya. Asal-usul identitas etnis Halmahera utara adalah cikal bakalnya lahir di Tanah Kao. Namun sekali lagi, hal ini tidak banyak diungkap dalam berbagai literatur sejarah lokal Halmahera Utara dan Maluku Utara.

Survei dan ekskavasi arkeologi di wilayah Desa Kao, Kecamatan Kao, adalah upaya menelusuri jejak Islamisasi di Halmahera Utara. Pada tradisi tutur masyarakat setempat, situs permukiman kuno atau Situs Kampung Tua Kao merupakan wilayah permukiman awal ketika masuknya Islam di wilayah pesisir pantai Kao dan Halmahera Utara. Menurut tradisi setempat pada masa awal Islam masuk di wilayah ini, masyarakat masih 'tafakur' atau kondisi berdiam diri. Pada masa ini adalah masa awal pengenalan Islam yang dibawa oleh seorang penyebar Islam bernama Syekh Al Mansyur, yang dipercaya datang dari Bagdad, Persia yang menurut informasi tutur masyarakat setempat seorang keturunan Bani Hasyim (Hasil percakapan dengan Zulfkifli Tukan, Juli 2014) (Tim Penelitian, 2014; Handoko, dkk., 2016; Handoko, 2017).

Penelusuran arkeologis menemukan buktibukti material, bahwa wilayah Tanah Kao peranannya sangat penting dalam perkembangan sejarah lokal di Halmahera Utara. 
Terutama dalam lintasan jaringan Islamisasi dan perkembangan peradaban pada pra-Islam, masa Islam, dan setelahnya. Terletak di pertemuan sungai Ake Jodo dan Ake Ngoali, di wilayah pedalaman Kao yang sekarang ditemukan buktibukti arkeologi berupa permukiman kuno dan data-data pendukungnya. Jejeran makammakam kuno, sebaran artefak-artefak kuno, dan lanskap permukiman masa lampau memperkuat dugaan bahwa situs itu menjadi fakta berlangsungnya peradaban yang cukup maju. Sebuah pedalaman terpencil dalam lanskap sungai, daratan dengan dataran yang luas, serta lahan-lahan basah hutan sagu, orang-orang memilih lokasi untuk bermukim dengan segala aktivitas yang mengikutinya di sana. Sungai Ake Jodo yang memanjang berkelok dari muara di pesisir Kao sekarang adalah pintu masuk bagi para migran dan pedagang asing untuk memasuki wilayah itu. Beberapa diantaranya juga diperkirakan melalui daratan luas, yang terletak di sebelah barat Kao sekarang.

Pada lokasi permukiman kuno atau Kao Lama ini tersebar makam-makam kuno dengan jumlah besar pada areal yang termasuk wilayah permukiman. Namun, tidak semua makam-makam tersebut dapat diidentifikasi mengingat bentuk dan karakter makam yang tidak bisa dikenali lagi akibat sebagian ada yang sudah tertanam atau terdapat diantara rimbunan vegetasi. Meski

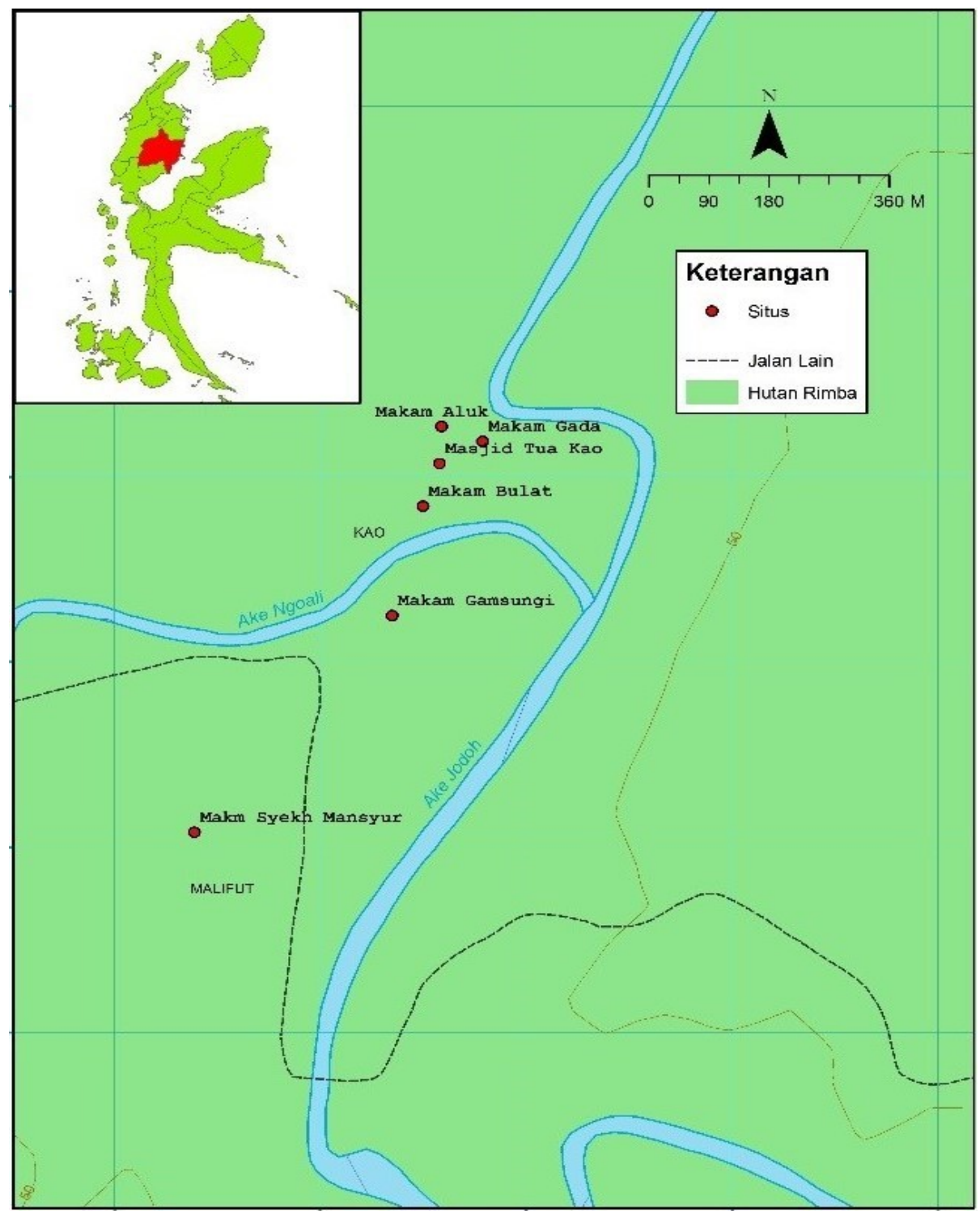

Gambar 2 Sebaran Tinggalan Arkeologis di Situs Kampung Tua Kao 
demikian, beberapa makam dapat diidentifikasi secara khusus karena bentuk jirat ataupun nisannya yang spesifik sehingga dapat membedakannya dengan bentuk jirat dan nisan makam lainnya.
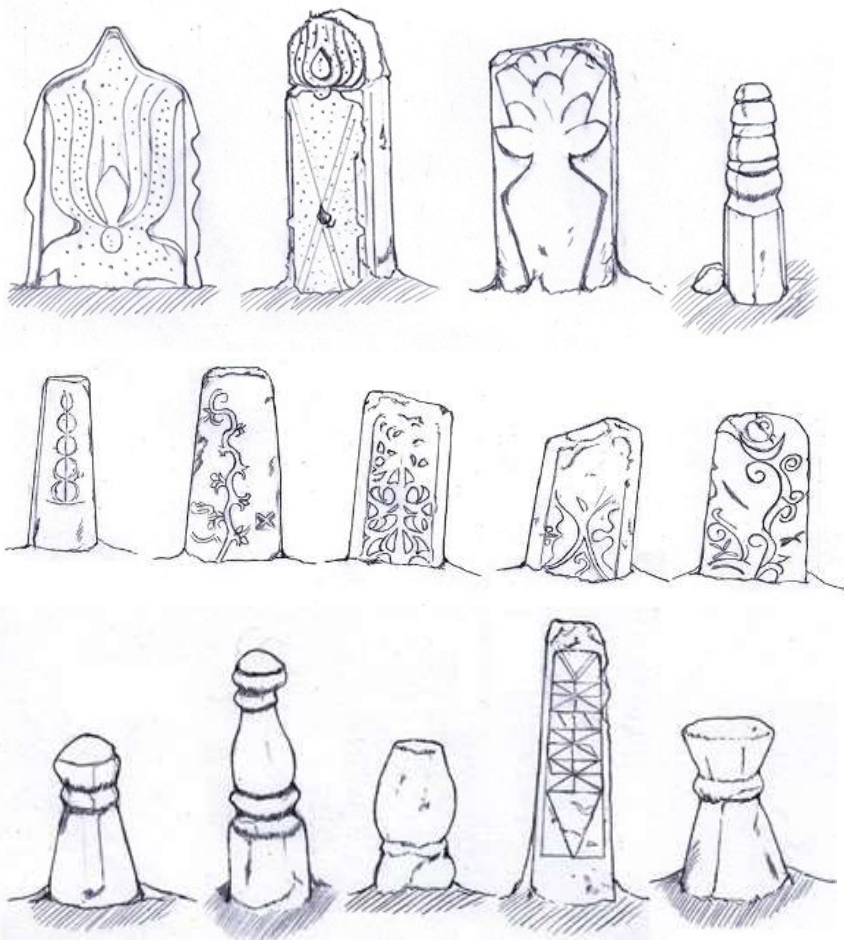

Gambar 3 Ragam Bentuk Nisan Makam di Situs Kampung Tua Kao

Pada umumnya bentuk makam yakni jirat dan nisannya merupakan bentuk makam yang sederhana, seperti bentuk jirat susunan batu dan nisan berupa nisan-nisan masif berupa batu menhir dalam berbagai ukuran. Namun, beberapa nisan juga memperlihatkan bentuk yang lebih kompleks baik dari segi pengerjaan (pahatan), maupun bentuk, ukiran, dan tipologinya. Situs makam yang paling populer adalah Makam Syekh Mansyur yang dipercaya sebagai penyiar Islam pertama di wilayah tersebut. Selain situs makam Syekh Al Mansyur di pedalaman Desa Kao yang berbatasan dengan Desa Popon, juga terdapat kompleks makam istri Syekh Al Mansyur beserta kerabat yang terletak 350 meter sebelah utara dari makam Syekh Al Mansyur. Pada kompleks tersebut selain makam Istri Syekh Al Mansyur, terdapat pula sembilan makam, yakni makam kerabat atau pengikutnya. Masyarakat me- nyebut lokasi makam sebagai Situs Gamsungi. Selain situs makam tersebut, di seberang sungai ditemukan kompleks makam dengan kuantitas banyak dan tersebar di daerah atau di bantaran Sungai Kalak atau Ake Ngoali yang merupakan percabangan dengan sungai Akejodo. Pada tengah percabangan Sungai Akejodo dan Air Kalak inilah situs permukiman kampung tua Kao berada. Permukiman dan sebaran makam-makam berada di sepanjang tepian atau bantaran sungai di atas permukaan tanah dengan kontur tanah yang variatif (Tim Penelitian, 2014; Handoko dkk., 2016; Handoko, 2017).

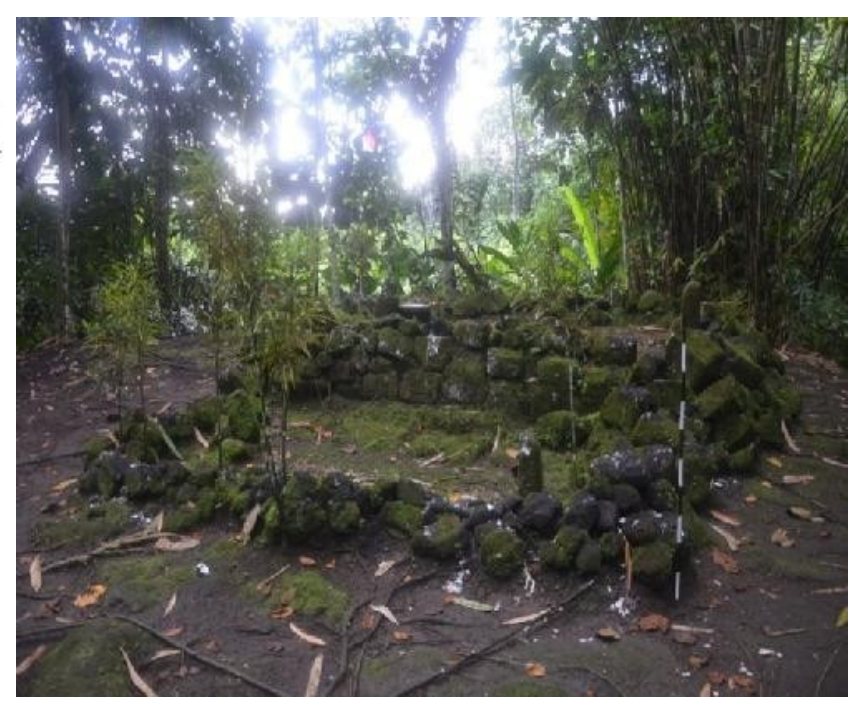

Gambar 4 Makam Syekh Al Mansyur dan Muridnya

Kedatangan Islam menimbulkan pengaruh ekonomi yang cukup besar terhadap pulau-pulau di wilayah Maluku Utara, termasuk wilayah Halmahera Utara. Penyebaran Islam erat hubungannya dengan perkembangan perdagangan internasional. Hal ini terlihat bagaimana perkembangan pos-pos perdagangan di Ternate, Galela, dan Kao. Posisi Kao berdasarkan penelitian ini menempati posisi yang sangat penting bagi perkembangan peradaban Islam, baik hubungannya dengan kekuasaan Ternate maupun posisi wilayah Kao sendiri dalam perkembangan Islam di jazirah Halmahera Utara. Bukti-bukti arkeologis di Kampung Tua Kao menjelaskan bahwa tanah Kao merupakan salah satu pusat peradaban Islam di Halmahera Utara 
dan dari sana kemudian Islam semakin berkembang ke wilayah lainnya di sepanjang pesisir Halmahera Utara.

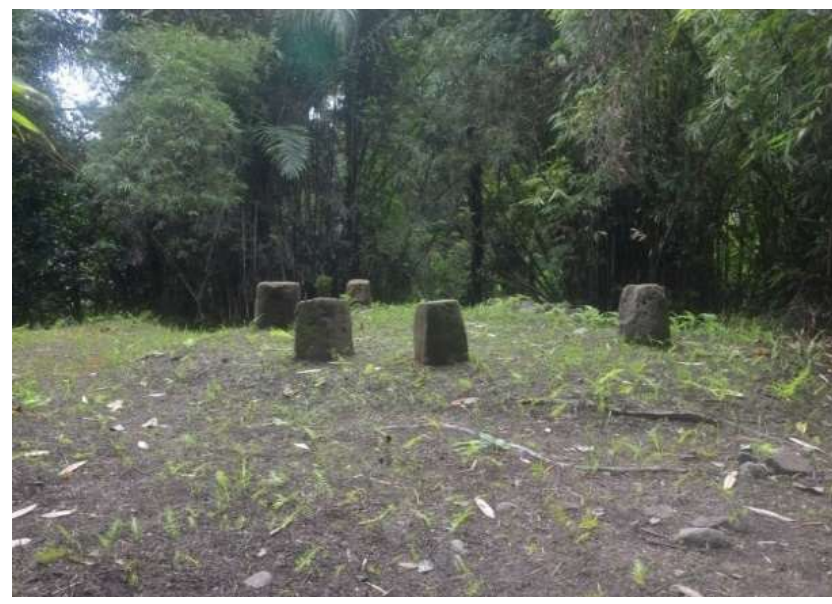

Gambar 5 Umpak-umpak Bekas Tiang Masjid

Secara keseluruhan, kawasan situs permukiman lama Kao atau Situs Kampung Tua Kao terdiri dari tiga kluster situs, yakni: Situs Makam Kuno Syekh Al Mansyur dan muridnya yang terletak di daerah bukit di Desa Popon; makam istri Syekh Al Mansyur beserta pengikutnya, yang terletak $500 \mathrm{M}$ di sebelah barat makam Syekh Mansyur, atau masyarakat menyebut lokasi tersebut dengan sebutan Kampung Gamsungi; dan Situs Permukiman Lama, di sebelah barat Situs Makam Istri Syekh Al Mansyur dan pengikutnya yang terletak di seberang Sungai Air Kalak. Pada area lokasi situs permukiman, selain terdapat banyak sebaran makam-makam kuno, juga situs atau lokasi bekas Masjid Kuno Kao Lama. Hal tersebut ditandai adanya temuan sebaran umpak-umpak yang tertata rapi, tampak menunjukkan pola keletakan tertentu yang diduga sebagai bekas umpak tiang penyangga Masjid Kao Lama yang berjumlah 12 sesuai dengan konstruksi masjidmasjid kuno pada umumnya di Maluku (Handoko, 2013; Handoko, 2016; Handoko, 2017). Situs bekas masjid kuno menempati areal yang lebih tinggi dibanding daerah sekitar yang kemungkinan dimanfaatkan sebagai lokasi hunian.

Masyarakat tradisional di wilayah Maluku adalah masyarakat yang sangat kuat mempertahankan tradisi sehingga ketika Islam masuk, anasir-anasir budaya lokal tidak bisa dihilangkan begitu saja. Bentuk-bentuk akomodatif Islam dengan budaya lokal, dalam berbagai aspek dapat ditinjau dari karakteristik budaya material yang dihasilkan baik itu berbentuk bangunan atau fitur maupun data artefaktual.

Salah satu data arkeologi yang dapat menggambarkan bagaimana keberagamaan Islam masyarakat lokal adalah wujud fisik makam-makam kuno (Handoko, 2014). Sejumlah nisan kuno dan lokasi situs masjid kuno yang meninggalkan jejak umpak-umpak tiang masjid, menjadi bukti peradaban Islam yang berkembang. Situs Kampung Tua Kao tampak menjadi bukti adanya permukiman muslim di sana. Jejak-jejak permukiman yang maju dari sebaran artefaktual berupa gerabah tanah liat dan piring-piring impor merupakan tanda perjumpaan penduduk lokal dengan pedagang asing. Bukti-bukti makam kuno Islam dengan ciri tipologi dari wilayah-wilayah seberang, menjadi tanda perjumpaan penduduk lokal dengan para penyiar Islam dari tanah seberang. Tipologi makam yang tersebar hampir memenuhi lebih separuh areal situs, menjadi bukti intensitas penyebaran Islam di Tanah Kao. Tipologi makam kuno Islam, yang berciri makam Islam Aceh, Jawa dan juga Ternate serta ciri lokal, menjadi bukti bahwa masyarakat lokal berhubungan dengan para pedagang dan sekaligus penyebar Islam dari wilayah Sumatra, Jawa, dan juga kekuasaan Islam di Ternate itu sendiri.

Dalam sejarah lokal, Tanah Kao tidak bisa dilepaskan dari pusat kekuasaan Islam di Ternate. Ternate dikenal sebagai pusat kekuasaan Islam yang melebarkan sayap kekuasaannya ke wilayah-wilayah pinggirannya bahkan menyeberang jauh ke wilayah seberang lautan baik dalam lingkup kawasan kepulauan Maluku bahkan ke wilayah yang lebih jauh dari lingkup kawasan kepulauannya. Para Sangaji di wilayahwilayah ekspansi Islam Ternate adalah bukti ekspansi kekuasaan sekaligus penyebaran Islam dari Ternate. Tanah Kao adalah salah satu wilayah ekspansi Islam Ternate. Bukti-bukti 
sejarah dan arkeologi yang ditemukan di sana menjadi tanda bahwa Tanah Kao sangat penting di mata Ternate. Selain sebagai pemasok bahan kebutuhan pokok ke Ternate, diperkirakan Kao menjadi wilayah konsolidasi penyebaran Islam di Halmahera Utara.

Bukti-bukti arkeologi dan etnografi di wilayah Tanah Kao menjadi bukti perkembangan peradaban Islam di Halmahera Utara yang selama ini tidak terungkap di permukaan. Bagaimana pengaruh budaya dari luar yang masuk ke wilayah Kao mengalami proses asimilasi dan akulturasi dengan budaya lokal juga merupakan medan penelitian yang selama ini belum tergarap. Bukti-bukti arkeologi lainnya yang ditemukan diantaranya ialah alat permainan gacuk, yaitu tembikar berwarna merah, berbentuk bundar pipih, selama ini dikenal sebagai permainan anak-anak di Pulau Jawa. Temuan di wilayah pedalaman Kao menjadi bukti intensitas hubungan Jawa dan Halmahera Utara, baik dalam jaringan niaga maupun penyebaran budaya dan penyebaran Islam. Hal ini juga menjadi bagian dari sejarah perkembangan peradaban di Tanah Kao.

Hubungan Kao dengan wilayah lain, baik dalam ekskalasi niaga maupun penyebaran Islam diperlihatkan oleh sebaran temuan artefakartefak keramik. Temuan sejumlah artefak keramik selain ditemukan tersebar di atas permukaan tanah, juga ditemukan dari hasil ekskavasi. Artefak-artefak keramik yang ditemukan antara lain diidentifikasi sebagai keramik Eropa abad ke-19 hingga abad ke-20, keramik Cina dari Dinasti Qing abad ke-17, dan Dinasti Ming abad ke-18 hingga abad ke-19. Keramik-keramik Cina dan Eropa, yang dibawa langsung oleh pedagang Cina maupun pedagang-pedagang pengumpul baik dari wilayah Maluku, Jawa, dan Sumatara (Melayu), menjadi bukti adanya mekanisme niaga, yang sekaligus jaringan ekonomi antara pedagang lokal dan pedagang asing, baik di wilayah pesisir maupun wilayah pedalaman (Handoko, 2007). Bentuk wilayah Nusantara yang berupa kepulauan menjadikan laut, selat, dan sungai yang saling terhubung membentuk jalur pelayaran dan perdagangan yang ramai (Mujabuddawat, 2015). Keramik asing yang ditemukan di situs-situs arkeologi di wilayah Maluku dapat menandai ramainya aktivitas perdagangan pada masa lampau (Handoko, 2007). Bukti-bukti peran penguasa dalam jaringan ekonomi bisa ditelusuri karenanya. Selain itu, proses penyebaran Islam, sekaligus melalui jalan niaga dan penguasaan ekonomi membuktikan bahwa terjadi mekanisme dan cara-cara Islamisasi yang kompleks, yang diperkirakan melibatkan para penguasa. Hal ini menjadi bukti peradaban yang sangat maju, di samping memberikan pemahaman kepada kita,

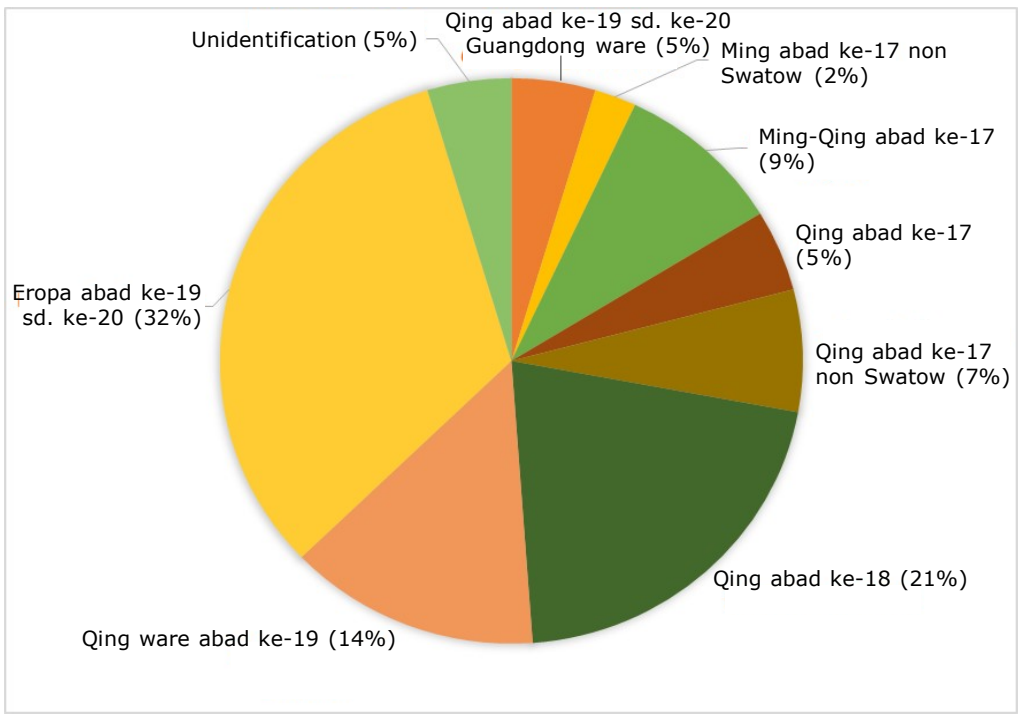

Gambar 6 Diagram Identifikasi Perolehan Artefak Keramik di Situs Kampung Tua Kao 
bahwa penyebaran Islam melalui mekanisme pertumbuhan niaga dan ekonomi serta politik ekspansionisme menjadi mata rantai eksistensi Islam itu sendiri.

\section{Jejak dan Perkembangan Sufisme Islam}

Mayoritas para ahli sepakat bahwa Islam di wilayah nusantara berkembang sejak awalnya dengan corak tasawuf atau sufisme (Azra, 2009; Idham, 2011). Selain itu, karakteristik Islam awal yang berkembang juga dapat menjadi bahan interpretasi, bahwa karisma-karisma para penyebar Islam secara individu juga menjadi daya tarik masyarakat lokal mengkonversi diri ke agama Islam. Ketokohan Syekh Mansyur, dalam berbagai tradisi tutur, memperlihatkan penghormatan dan sakralitas sebagai syekh atau penyebar Islam yang penuh aura mistik. Ketokohannya memperlihatkan bagaimana Islam dipahami dalam cara pandang tradisionalisme sufi. Data arkeologi berupa makam Syekh Mansyur di tempat yang tinggi, menjadi bukti sakralitasnya. Selain itu, ada tradisi penghormatan melalui ritual ziarah makam yang dikenal ritual tagi jere, yaitu ritual ziarah atau mengunjungi makam keramat yang menjadi tradisi kuat dalam komunitas etnik Kao di Halmahera Utara. Tradisi ritual tersebut sarat dengan nilai-nilai religius yang dapat dilihat sebagai ciri khusus dan penegasan akan identitas Muslim mereka dari segi budaya (Manan, 2014). Ritual tagi jere menjadi bukti bahwa perlakuan terhadap orang yang dimakamkan dengan cara menyucikan atau mengeramatkan makam merupakan bukti berkembangnya sufisme yang menciptakan tradisi ziarah keramat.

Perkembangan tarekat-tarekat sufi lain, yaitu munculnya sejumlah tokoh Syekh, menyebabkan pengeramatan sejumlah besar wali-wali yang sudah meninggal dan tokoh-tokoh itu merupakan sebagian besar dari fenomena ziarah. Hal tersebut menjadi bukti bahwa perkembangan tradisionalisme sufi adalah salah satu ciri spesifik perkembangan Islam di masyarakat lokal sebagai bagian dari peng- hormatan terhadap arwah leluhur, tanpa meninggalkan keislamannya. Selama ini, sejarah peradaban Tanah Kao sebelum pelacakan arkeologis sangat tersembunyi dan hanya diketahui oleh sebagian kecil masyarakat di sana. Hasil pelacakan sejarah dan peradaban Islam di Tanah Kao, Halmahera Utara, melalui bukti-bukti arkeologi, menunjukkan betapa dinamisnya budaya dan peradaban di sana.

Data arkeologi melalui sebaran data artefaktual, terutama keramik asing dapat menjadi bahan untuk mengidentifikasi perkembangan permukiman di wilayah itu. Data persebaran keramik dapat mengkonfirmasi bagaimana intensitas penggunaan perkakas keramik asing sebagai peralatan rumah tangga sehari-hari dan menyangkut pertukaran komoditi yang berkembang di wilayah itu. Intensitas perdagangan dan mobilitas penduduk, melalui jalur sungai menuju pantai, dapat menggambarkan bahwa permukiman di wilayah tersebut sudah demikian padat. Selain itu, temuan sebaran makam-makam kuno Islam di wilayah tersebut dapat memberikan keterangan tentang dinamika perkembangan demografi di wilayah itu. Banyaknya temuan makam-makam kuno Islam memberikan gambaran bahwa Situs Kampung Tua Kao merupakan situs permukiman yang cukup padat pada masa itu.

\section{SIMPULAN DAN SARAN \\ Simpulan}

Leluhur penduduk yang sekarang disebut Kabupaten Halmahera Utara adalah campuran antara orang dengan latar kebudayaan dan bahasa Austronesia dan non-Austronesia. Identitas asal-usul komunitas yang sekarang bermukim di wilayah Halmahera Utara dapat dirunut ke belakang. Semuanya berasal dari wilayah Telaga Lina, sebuah wilayah yang termasuk dalam wilayah daratan Tanah Kao sekarang. Dengan demikian, komunitas Orang Kao merupakan komunitas suku yang dapat ditempatkan peranannya dalam penjelasan soal identitas asal-usul komunitas Halmahera Utara. 
Berdasarkan penelitian arkeologi di Situs Kampung Tua Kao, ditemukan berbagai bentuk tinggalan arkeologis yang membuktikan adanya permukiman manusia. Tinggalan-tinggalan arkeologis yang ditemukan antara lain temuan artefaktual yaitu ragam fragmen gerabah, keramik, dan artefak lainnya, ada pula tinggalan berupa fitur yaitu makam-makam tua, nisan makam, lutur, dan umpak-umpak masjid tua. Berdasarkan bukti data-data penelitian arkeologi dapat menjelaskan bahwa Tanah Kao sudah menjadi bagian kekuasaan Ternate sejak abad ke-16. Hal ini sesuai dengan informasi tutur yang menyebutkan bahwa permukiman kuno Islam di bantaran sungai Aer Kalak berkembang sejak abad itu. Data arkeologi keramik, yang berasal dari Dinasti Qing dan Ming abad ke-17 hingga ke-18, dapat mengonfirmasikan data sejarah tersebut. Informasi kesejarahan yang penting menyangkut adanya temuan situs permukiman Kampung Tua Kao di wilayah pedalaman yakni di wilayah Daerah Aliran Sungai (DAS) Kao atau lebih tepatnya yang mengarah ke aliran sungai Aer Kalak atau sungai Ake Jodo, mengungkapkan bahwa permukiman tua di bantaran sungai itu merupakan bekas permukiman komunitas muslim. Hal tersebut dapat dihubungkan dengan fakta-fakta sejarah yang berhubungan dengan wilayah Halmahera Utara lainnya.

\section{Saran}

Penelitian lanjutan terhadap arkeologi di lokasi Situs Kampung Tua Kao perlu ditindaklanjuti, terutama difokuskan pada penelusuran Sungai Ake Jodo ke arah utara hingga menemukan hulu sungai yang diperkirakan adalah situs Telaga Lina yang merupakan lokasi asal Orang Halmahera Utara. Di samping itu, penelitian untuk mengetahui kronologi penyebaran komunitas Orang Kao dan pencarian data arkeologis yang lebih tua akan menjadi hal yang menarik yang dapat membuka wawasan arkeologi di masa yang akan datang.

\section{PUSTAKA ACUAN}

Amal, M. A. 2010. Kepulauan Rempah-rempah Perjalanan Sejarah Maluku Utara 1250-1950. Jakarta: Kepustakaan Populer Gramedia (KPG).

Ambary, H. M. 1996. Menemukan Peradaban Arkeologi dan Islam di Indonesia. Jakarta: Logos Wacana IImu.

Asyhari, M. 2008. Status Tanah-tanah Kesultanan Ternate dalam Perspektif Tanah Nasional. Mimbar Hukum, 20(2),352-366.

Azra, A. 2009. Arkeologi Islam Indonesia: Sebuah Penghargaan untuk Uka Tjandrasasmita. In Arkeologi Islam Nusantara. Jakarta: Kepustakaan Populer Gramedia (KPG).

de Graaf, H. J. 1956. De Historische Betrouwbaarheid Der Javaanse Overlevering. Bijdragen Tot de Taal-, Land- En Volkenkunde, 112(1),55-73.

Diense, A. H., \& Thaib, R. 2008. Ternate (Sejarah Kebudayaan \& Pembangunan Perdamaian Maluku Utara). Ternate: Lekra-MKR.

Ghofur, A. 2011. Tela'ah Kritis Masuk dan Berkembangnya Islam di Nusantara. Jurnal Ushuluddin, XVII(2),159-169.

Handoko, W. 2007a. Aktifitas Perdagangan Lokal di Kepualuan Maluku Abad 15 M - 19 M. Kapata Arkeologi, 3(4),100-120.

Handoko, W. 2007b. Asal-Usul Masyarakat Maluku, Budaya, dan Persebarannya: Kajian Arkeologi dan Mitologi. Kapata Arkeologi, 3(5),1-27.

Handoko, W. 2013. Karakteristik Arsitektur Masjid Kuno dan Perkembangan Islam di Maluku. Amerta, 31(1),39-52. 
Handoko, W. 2014. Tradisi Nisan Menhir pada Makam Kuno Raja-raja di Wilayah Kerajaan Hitu. Kapata Arkeologi, 10(1),33-46.

Handoko, W. 2016. Islam Negeri Kaitetu: Relasi Islam, Adat dan Pemerintahan Lokal. Kota Ambon: Universitas Pattimura.

Handoko, W. 2017. Ekspansi Kekuasaan Islam Kesultanan Ternate di Pesisir Timur Halmahera Utara. Kapata Arkeologi, 13(1),95-108. https://doi.org/10.24832/kapata.v13i1.396

Handoko, W., Mujabuddawat, M. Al, Huwae, A., Husni, M., Karolina, J., \& Latupapua, S. 2016. Tanah Kao: Menguak Identitas Asal Usul Komunitas, Sejarah, dan Peradaban Islam di Halmahera Utara. Ambon: Tidak terbit.

Idham. 2011. Naskah Klasik di Kota Tidore Kepulauan Provinsi Maluku Utara. Jurnal Manassa, $1(1), 79-96$.

Leirissa, R. Z. 1990. Masyarakat Halmahera dan Raja Jailolo: Studi tentang Sejarah Masyarakat Halmahera Utara. Depok: Universitas Indonesia.

Manan, M. A. 2014. Ritual Tagi Jere dalam Komunitas Etnik Kao: Peran Lembaga Dewan Adat dan Badan Syara' dan Perkembangannya. Jurnal Masyarakat \& Budaya, 16(1),27-50.

Mansyur, S. 2007. Peninggalan Arkeologis di Kepulauan Bacan. Kapata Arkeologi, 3(4),74-99.

Mujabuddawat, M. Al. 2015. Kejayaan Kesultanan Buton Abad Ke-17 \& 18 dalam Tinjauan Arkeologi Ekologi. Kapata Arkeologi, 11(1),21-32.

Mujabuddawat, M. Al. 2016. Simbolisme Kompleks Bangunan Situs Ki Buyut Trusmi Cirebon. Kapata Arkeologi, 12(2),175-190.

Naping, H. 2013. Halmahera Utara, Sejarah Perkembangan Peradaban di Bumi Hibua Lamo. Makassar: Universitas Hasanuddin, Pemerintah Kabupaten Halmahera Utara, dan Yayasan Bina Generasi.

Nomay, U. 2014. Orang Melayu di Kota Ternate Abad XV-XIV. Jurnal Al-Qalam, 20(2),245-254.

Papilaja, E. J. 2011. Kharisma Hibualamo (Tutur Kearifan Kepemimpinan Budaya). Jakarta: Dinas Pariwisata dan Budaya Halmahera Utara.

Poesponegoro, M.D. \& Notosusanto, N. 2008. Sejarah Nasional Indonesia III. (B. Sumadio, Ed.). Jakarta: Balai Pustaka.

Puasa, A. 2013. Falsafah Hibualamo Suatu Upaya Membangun Rekonsiliasi di Halmahera Utara. Jurnal Uniera, 2(1),1-8.

Putuhena, S. M. 1995. Penyebaran Agama Islam di Maluku. Makassar: Balai Penelitian dan Pengabdian pada Masyarakat IAIN Alauiddin.

Soegondho, S. 1995. Earthenware Traditions in Indonesia: From Prehistory Until the Present (1st ed.). Jakarta: Ceramic Society of Indonesia.

Tim Penelitian. 2014. Laporan penelitian: Arkeologi Islam di Wilayah Pesisir Timur Kabupaten Halmahera Utara. Ambon: Tidak terbit.

Tjandrasasmita, U. 1998. Arti Arsitektur Mesjid-mesjid Kuno di Indonesia. Jakarta: Fakultas Sastra Universitas Indonesia.

Tjandrasasmita, U. 2009. Arkeologi Islam Nusantara. Jakarta: Kepustakaan Populer Gramedia (KPG).

Wimbish, S. G. 1991. An Introduction to Pagu through the Analysis of Narrative Discourse. The University of Texas at Arlington.

Yatim, B. 2006. Sejarah Peradaban Islam: Dirasah Islamiyah II. Jakarta: PT Raja Grafindo Persada. 